appointment that the numerous inquiries and conferences held during the past year have not yet had any result. Local investigation with regard to the movements of herring shoals is insufficient. In this case the shoals leave Northumbrian waters and appear later on off the Firth of Forth, where, apparently, they are not sampled or investigated. It is therefore regrettable, Prof. Meek suggests, that reconstruction should have been a departmental rather than a national affair.

\section{J. J.}

\section{Flora of the Hawaian Islands.}

THE natural history of the Hawaian Islands has been well worked as regards both the flora and the fauna. Generally speaking, there is an extraordinary degree of endemism in the plants and animals, associated with a strong Southern Pacific or Australasian and Indo-Malayan affinity and a weak Northern Pacific or American affinity. The islands are extremely isolated, being further removed from any continental area than is any other region of equal size upon the globe. The nearest continent is North America, two thousand miles away, and the nearest islands of any importance, the Marquesas, are I860 miles distant. Within forty miles of the shores the ocean exceeds $10,000 \mathrm{ft}$. in depth, and between the islands and the American coast reaches in places more than $20,000 \mathrm{ft}$. The most commonly accepted view of the origin of the archipelago is that the islands, which are entirely volcanic, were raised by volcanic activity, and that they have always been completely isolated.

In a paper entitled "The Derivation of the Flora of Hawaii" (Leland Stanford Junior University Publications, University Series, I9I9) Prof. D. H. Campbell gives a résumé of the composition of the flora and its relations to American and Southern Pacific foras generally, and criticises unfavourably Guppy's view of its origin and distribution. Guppy accepts the view that the archipelago has always been completely isolated, and that air-currents and birds have been the agents concerned in its population. The predominantly Australasian and Indo-Malayan element was, he suggests, introduced largely by birds, especially fruit-eating pigeons, but Prof. Campbell finds a serious objection in the absence of such birds from the present fauna, as, apart from a number of American migratory shore-birds, practically all are endemic. Prof. Campbell strongly supports the view taken by Mr. H. A. Pilsbry, based on the study of the molluscan fauna. The land-snails are all ancient types the modern representatives of which are largely confined to Polynesia, and they represent, it is contended, an ancient fauna which has survived from a time when Hawaii was part of a continental area connected to the south-west with that of Polynesia. A study of the insects leads to a similar general conclusion, namely, that while the ancestors of some of the species mav have been introduced through the agency of wind- or ocean-currents or by migratory birds, there are many more species of both plants and animals the presence of which can best be explained by a former more or less direct land-connection between Hawaii and the Indo-Malavan region.

The multitude of islands constituting Polvnesia are. on this hypothesis, the remains of a once extensive land-mass, either a single continent or several large continental islands like Australia. This great area has been subsiding since Early Tertiary times, and the existing islands are the tnos of mountain masses. often volcanic, superimnosed upon this submerged continental area. A serious objection to this theory is the absence in Hawail of certain types of vegetation characteristic of Southern Pacific regions, such as the conifers, aroids, and figs, and it is suggested that these forms became extinct after the isolation of the islands. Similar examples of such disappearance of plants are afforded by Sequoia, Liriodendron, and other genera, which had once a wide distribution, but are now represented in many regions only by Tertiary fossils.

\section{University and Educational Intelligence.}

Dr. J. B. Cleland, of the Health Department of New South Wales, has been appointed to fill the newly constituted chair of pathology in the University of Adelaide, South Australia.

Applicatrons for grants from the Dixon Fund, of the University of London, for assisting scientific investigations, are receivable by the Academic Registrar, University of London, South Kensington, S.W.7, until May 14 next. They must be accompanied by the names and addresses of two referees.

The Marguess of Crewe, chairman of the governing body of the Imperial College of Science and Technology, and Sir Alfred Keogh, Rector of the college, will attend the annual dinner of the Old Students Association of the Royal College of Science, to be held at the Café Monico on Saturday, April 24. Other distinguished guests will be Prof. W. H. Bragg, Dr. W. Garnett, Sir Richard Glazebrook, Mr. W. McDermott, and Sir Ronald Ross. Tickets (price Ios. 6d.) may be obtained from Mr. C. S. Garland, acting secretary, Old Students Association, Royal College of Science, South Kensington, London, S.W.7.

Aт a general meeting of old students held recently at King's College, Strand, it was decided to form a King's College, London, Old Students' Association for the purpose of promoting social intercourse and of keeping the members in touch with their old college. The association hopes to include students from all faculties, and the subscription of ros. $6 d$. per annum will include the King's College Review, published once a term, and a list of members with their addresses (and possibly the work on which they are engaged). Further particulars and forms of application for membership may be obtained from Miss M. A. V. Fairlie, hon. secretary, 3 St. Julian's Farm Road, West Norwood, S.E.27.

\section{Societies and Academies.}

Faraday Society, March 1.-Dr. T. Martin Lowry and F. C. Hemmings: The properties of powders. The caking of salts is, in general, dependent on the presence of a solvent, usually water. The following cases have been studied: Nitrates, other anhydrous compounds, hydrated salts, loss of sulphur dioxide during caking and contraction during caking of copper sulphate.-Dr. T. Martin Lowry and S. Wilding: The setting of dental cements. Phenomena of caking or setting may be divided into five classes:-(r) Recrystallisation of anhydrous or hydrated salt without change of chemical composition. (2) Formation of hydrates. (3) The hydrolysis of complex salts by water. (4) The formation of new salts, such as the magnesium oxy-cements and the zinc oxy-phosphate cements used in dentistry, and "silicate" cements. (5) Amalgams in which mercury takes the place of water.

Zoolegical Society, March 16.-Prof. E. W. MacBride, vice-president, in the chair.-R. I. Pocock : NO. 2633 , VOL. I05] 